\title{
Using systems thinking to design actionable futures: a nuclear weapons example
}

\author{
Leon D. Young(1)
}

\begin{abstract}
It is a general observation that foresight is analogised with forecast. Yet foresight, or futures thinking, is not predictive or deterministic. The misperception appears to be based on the belief that foresight does not often result in tangible results that are immediately applicable within an executive or policy decision arena. Foresight, it is assumed, is unfounded on reality and thus not relevant to fast tempo or strategic level operations. This paper contends that the use of evidence-based methods allows foresight work to be immediately operational and useful.

Using a case study of nuclear weapon security within Pakistan, this paper explores the structured use of systems thinking, scenario development and options analysis to develop plausible, feasible and actionable strategic policy options. The case study demonstrates that it is possible to develop quantifiable options derived out of traditional foresight methods. This paper argues that useful foresight needs to be tangible and provide feasible options.
\end{abstract}

Keywords: Systems thinking, National strategy, Scenario development, Security policy, Options analysis, Foresight

\section{Introduction}

Drawing from a multi-discipline perspective, this paper describes a novel methodology for developing evidencebased, actionable strategic options. The use of evidence is intentional as one of the perceived problems in using future methodologies is that they are often difficult to trace or have an inadequate 'audit trail' ([1] p. 8). That is, when presenting the findings of a foresight-driven analysis to an executive board, the most common question is either "so what?" or "what can we do about it?" Knowing what the future could look like tells us neither where we need to go nor how to get there. This article proposes a simple process that enables you to construct actionable and desirable options founded in your meaningful narratives of the future.

It appears that about half of the articles published in this journal over the last 2 years have been attempts at

\footnotetext{
Correspondence: l.young@futurestrategicthinking.com

This is theoretical case study based on a fictional example developed for post-graduate course work. The sole intent of this work is demonstrate the value of an evidence-based methodology to develop future strategic options in a complex geo-political problem. The results do not reflect any official policy.

Future Strategic Thinking, Canberra, Australia
}

forecasting. That is, they are strong research articles that describe the possible future $[2,3]$. Of the remaining articles, the majority appear to discuss scenario development methodology [4, 5], strength of organisational foresight [6] or establishing validity of future scenarios [7]. Some even look at the desirability of the futures [8]. While useful, as they all contribute to our body of knowledge, there appears to be little focus on creating actionable solutions. This article will address this perceived gap and seek to describe how the structured use of systems thinking in foresight allows the development of evidence-based and feasible options for organisations.

Using an example of nuclear de-stabilisation, this article demonstrates a process that asks what is (1) possible, (2) probable, (3) actionable and (4) desirable. The possible is discovered through more traditional scenario development methods. The probable is explored using modelling and simulation while the Threats-Opportunities-Weaknesses-Strengths (TOWS) method is used to find the actionable options. Finally, 
this article illustrates how multi-criteria decision analysis (MCDA), risk analysis and stakeholder analysis allow us to understand which options can be considered to be desirable to the decision maker.

\section{Background problem and method}

The problem example used in this article is derived from the 2009 book 7 deadly scenarios: a military futurist explores war in the 21st century by Krepinevich A.F where a crisis in Pakistan is described ([9], p. 30). This article assumes a position that represents the interests of the National Security Council (NSC) of a small to medium size western nation in the region. The NSC requires immediate strategic options that are actionable and are capable of furthering their interests in the region. In short, the background is:

The situation in Pakistan is deteriorating rapidly as the threat presented by the break-away Islamic Army Faction (Islamists) and associated Militant/Terrorist groups (Militants) increase. The Pakistan government is no longer functioning in its normal state and, as a consequence, the internal stability of Pakistan is wavering. The majority of the Army is loyal to the government (Loyalists) and has control over most of the country however is under constant pressure from the Islamic Faction. Additionally they have lost control of several nuclear warheads and are unsure of their locations. Fortunately all of the conventional delivery systems are still controlled by the Loyalists although it is possible to convert the missing warheads into 'dirty' bombs. The international community is observing and reluctant to interfere. This is due, in part, to the inability of most nations to contribute sufficient forces to have an impact on the situation in Pakistan. The nations that do have the forces (India and the United States of America) are unlikely to be welcome in Pakistan.

Employing a multi-disciplinary method that draws strongly from Foresight, Systems Thinking and Operations Research, a four-step process is used to develop strategic options for the National Security Council:

1. What is POSSIBLE? The initial step should be familiar to readers as it is simply the formation of a set of possible scenarios using a combination of mind maps, impact wheels and scenario development methods. In this case, as we are maximising the development of evidence, the Field Anomaly Relaxation (FAR) method is used.

2. What is PROBABLE? While FAR, and many other scenario development methods, are able to weed out wildly improbable future narratives, this step draws from the systems thinking literature to model and simulate the environment. The aim of this step is to understand the points in the environment that can be influenced-the levers of change. This will be achieved, in this case, through the use of stock and flow models.

3. What is ACTIONABLE? Levers of change can also be expressed as environmental threats and opportunities. The method used in this step is a three-part Threat-Opportunities-WeaknessesStrengths (TOWS) method. The key outcome of this stage is a number of feasible and distinct strategic options that are able to create change towards the preferred future.

4. Which options are DESIRABLE? The final step combines strategic risk analysis with multi-criteria decision analysis (MCDA) to understand relative cost-benefit ratios of the options and decision maker preferences. The key outcome is the development of a final option that is feasible, actionable and preferred by the decision makers.

\section{Step 1: What is possible?}

There are a large range of methods that can be used in this step and can be, admittedly, the most intensive step of this process. The three most common methods for this process are trend analysis, causal layer analysis and some sort of morphological analysis. The key outcomes are a set of scenarios, and a list of potential 'levers' that can be influenced by the client-in this case a national security apparatus. Trend analysis is useful but does not provide sufficient cross-domain analysis and does not allow the investigation of surprise events. As an investigative method, causal layer analysis is very useful in developing an understanding of the underlying problems and developing appropriate strategies to address these problems ([10], p., 816, [11]). While potentially suitable for this method, CLA appears to suffer from some confusion in application and would appear to suffer from the problems of other soft methods (such as Soft Systems Methodology) [12].

As a researcher, I would like to see CLA applied to this process; however, due to familiarity and a clear auditable evidence-based methodology, the Field Anomaly Relaxation (FAR) method was used [13]. This article will not go into describing the FAR method. Rather, this article will briefly cover the output and why they are useful. Firstly, FAR requires a clear bounding of the problem through variables. The use of mind maps was employed to discover six significant drivers or variables. The articulation of these variables allows the reader to quickly understand how the scenario development is bounded. These variables are described in Table 1. 
Table 1 Variables developed through FAR and used in developing the scenarios

\begin{tabular}{llllll}
\hline Islamic Faction & Loyalists, & International Intervention, & Militants, & Nuclear Weapons & Internal Stability \\
\hline$F_{1}$ Dominating & $L_{1}$ Dominating & $I_{1}$ Welcomed and effective & $M_{1}$ Not supported and weak & $N_{1}$ Known and Safe & $S_{1}$ Strong and Stable \\
$F_{2}$ Strong & $L_{2}$ Strong & $I_{2}$ Welcomed but not effective & $M_{2}$ Not supported and strong & $N_{2}$ Known and unsafe & $S_{2}$ Stable \\
$F_{3}$ Weak & $L_{3}$ Weak & $I_{3}$ Not welcomed but effective & $M_{3}$ Supported but weak & $N_{3}$ Unknown and safe & $S_{3}$ Shaky \\
$F_{4}$ Ineffective & $L_{4}$ Ineffective & $I_{4}$ Not welcomed nor effective & $M_{4}$ Supported and strong & $N_{4}$ Unknown and unsafe & $S_{4}$ Unstable \\
& & & & & \\
& & $I_{5}$ No intervention & & \\
\hline
\end{tabular}

The variables are combined to create different worlds. For instance, $\mathrm{F}_{3} \mathrm{~L}_{2} \mathrm{I}_{5} \mathrm{M}_{3} \mathrm{~N}_{3} \mathrm{~S}_{3}$ would describe a world where Pakistan is starting to collapse due to emerging Islamic threat and the loss of nuclear weapons. In this case, this is the starting position of the scenario narratives and the foundation of the problem being addressed by the NSC. Because there are over 5000 potential scenario narratives, an internal consistency analysis reduces the possible scenarios down to a more manageable number ([14], p.68). Finally, we can, through the combination of 'like' worlds, develop a list of 12 possible worlds (Table 2).

These worlds are then placed on a timeline in an attempt to understand logical changes and possible outcomes. The result of this process is illustrated in Fig. 1. Here, we can see the development of three distinct end-world and the potential scenario paths. Aside from creating a very simple illustration that is easily described to decision makers, descriptive narratives can be created. For instance:

Table 2 List of the final 12 worlds after congruence analysis and combination of like worlds

\begin{tabular}{|c|c|c|}
\hline Letter & Combination & Explanation \\
\hline$P$ & $\mathrm{~F}_{3} \mathrm{~L}_{2} \mathrm{I}_{5} \mathrm{M}_{3} \mathrm{~N}_{3} \mathrm{~S}_{3}$ & $\begin{array}{l}\text { Pakistan is starting to collapse due } \\
\text { to emerging Islamic threat and } \\
\text { loss of nuclear weapons }\end{array}$ \\
\hline $\mathrm{R}$ & $\left.\mathrm{F}_{1 / 2} \mathrm{~L}_{4}\right|_{5} \mathrm{M}_{3} \mathrm{~N}_{3} \mathrm{~S}_{2}$ & Islamic Republic is formed \\
\hline L & $\mathrm{F}_{4} \mathrm{~L}_{1} \mathrm{l}_{1} \mathrm{M}_{1 / 3} \mathrm{~N}_{1 / 3} \mathrm{~S}_{2}$ & Limited intervention to support Loyalists \\
\hline S & $\mathrm{F}_{4} \mathrm{~L}_{1} \mathrm{I}_{5} \mathrm{M}_{1 / 3} \mathrm{~N}_{1 / 3} \mathrm{~S}_{1 / 2}$ & Loyalist guarantee stability in Pakistan \\
\hline | & $\mathrm{F}_{1 / 2} \mathrm{~L}_{3 / 4} \mathrm{I}_{4} \mathrm{M}_{3 / 4} \mathrm{~N}_{2 / 4} \mathrm{~S}_{4}$ & Unsuccessful international intervention \\
\hline A & $\mathrm{F}_{3} \mathrm{~L}_{2} \mathrm{l}_{3} \mathrm{M}_{1 / 2} \mathrm{~N}_{1 / 3} \mathrm{~S}_{2}$ & $\begin{array}{l}\text { Unpopular but successful International } \\
\text { intervention resulting in stability }\end{array}$ \\
\hline B & $\mathrm{F}_{3} \mathrm{~L}_{2} \mathrm{I}_{1} \mathrm{M}_{2} \mathrm{~N}_{1 / 3} \mathrm{~S}_{1 / 2}$ & Successful intervention \\
\hline $\mathrm{F}$ & $\mathrm{F}_{4} \mathrm{~L}_{2} \mathrm{l}_{1} \mathrm{M}_{1 / 3} \mathrm{~N}_{1 / 3} \mathrm{~S}_{2}$ & $\begin{array}{l}\text { Islamic Faction no longer a threat to } \\
\text { stability }\end{array}$ \\
\hline M & $\mathrm{F}_{2} \mathrm{~L}_{4} \mathrm{I}_{4} \mathrm{M}_{4} \mathrm{~N}_{4} \mathrm{~S}_{4}$ & $\begin{array}{l}\text { Militants and Islamic faction fight for } \\
\text { control }\end{array}$ \\
\hline C & $\mathrm{F}_{4} \mathrm{~L}_{4} \mathrm{I}_{4} \mathrm{M}_{4} \mathrm{~N}_{4} \mathrm{~S}_{4}$ & $\begin{array}{l}\text { Infighting amongst militants and Islamic } \\
\text { faction resulting in disintegration of } \\
\text { Pakistan }\end{array}$ \\
\hline N & $\mathrm{F}_{4} \mathrm{~L}_{1} \mathrm{I}_{1} \mathrm{M}_{1 / 3} \mathrm{~N}_{2} \mathrm{~S}_{3 / 4}$ & $\begin{array}{l}\text { Nuclear weapons are located but not } \\
\text { controlled }\end{array}$ \\
\hline U & $\mathrm{F}_{3} \mathrm{~L}_{2} \mathrm{I}_{2} \mathrm{M}_{4} \mathrm{~N}_{4} \mathrm{~S}_{3 / 4}$ & $\begin{array}{l}\text { Pakistan military loses control of the } \\
\text { nuclear weapons }\end{array}$ \\
\hline
\end{tabular}

1. Scenario F: No Collapse $\left(F_{4} L_{2} I_{1} M_{1 / 3} N_{1 / 3} S_{2}\right)$-The situation in Pakistan is deteriorating due to a rise in power of the Islamic faction and the militant groups based in the North of Pakistan. The Loyalist faction has requested international assistance which is provided by the UN. The multinational force is able successfully reduce the threat created by the Islamic faction and strengthen the position of the Loyalist Faction. This in turn reduces the power of the militants. The Loyalists hope to return rule to a democratically elected government in a short time.

2. Scenario C: Warlords Rule $\left(F_{4} L_{4} I_{4} M_{4} N_{4} S_{4}\right)$-The rise of the Islamic faction has resulted in the loss of control of a number of nuclear weapons. Due to the risk posed to the international community, India and the USA insert a strong contingent to nullify this risk. This move proves to be unpopular with the Pakistan people who lend their support to the Militant liberators. As their strength and influence increase, the militants start to target the Islamic faction for control of Pakistan. As the situation in Pakistan deteriorates rapidly, more international forces become involved. By this stage, the Loyalist faction has lost all influence as India and the USA attempt to establish a functioning government. The situation is unresolved in the short term. In the long term, it is unlikely that the traditional political parties will gain control. It is more likely that an arrangement will be made handing more power to the Islamic faction.

3. Scenario R: Islamic Republic $\left(\mathrm{F}_{1 / 2} \mathrm{~L}_{4} \mathrm{I}_{5} \mathrm{M}_{3} \mathrm{~N}_{3} \mathrm{~S}_{2}\right)$-The Islamic faction swiftly gain control of the nuclear weapons prompting an immediate response from India and the USA. This move is unwelcome amongst the Pakistan people who throw their support behind the Islamists. The international intervention fizzles and the USA reluctantly accepts that they are unlikely to win. As India does not want a border with an insecure and unstable nation, they recognise the newly proclaimed Islamic Republic.

FAR makes it easy to understand where the potential branches are. From a military or security point of view, 


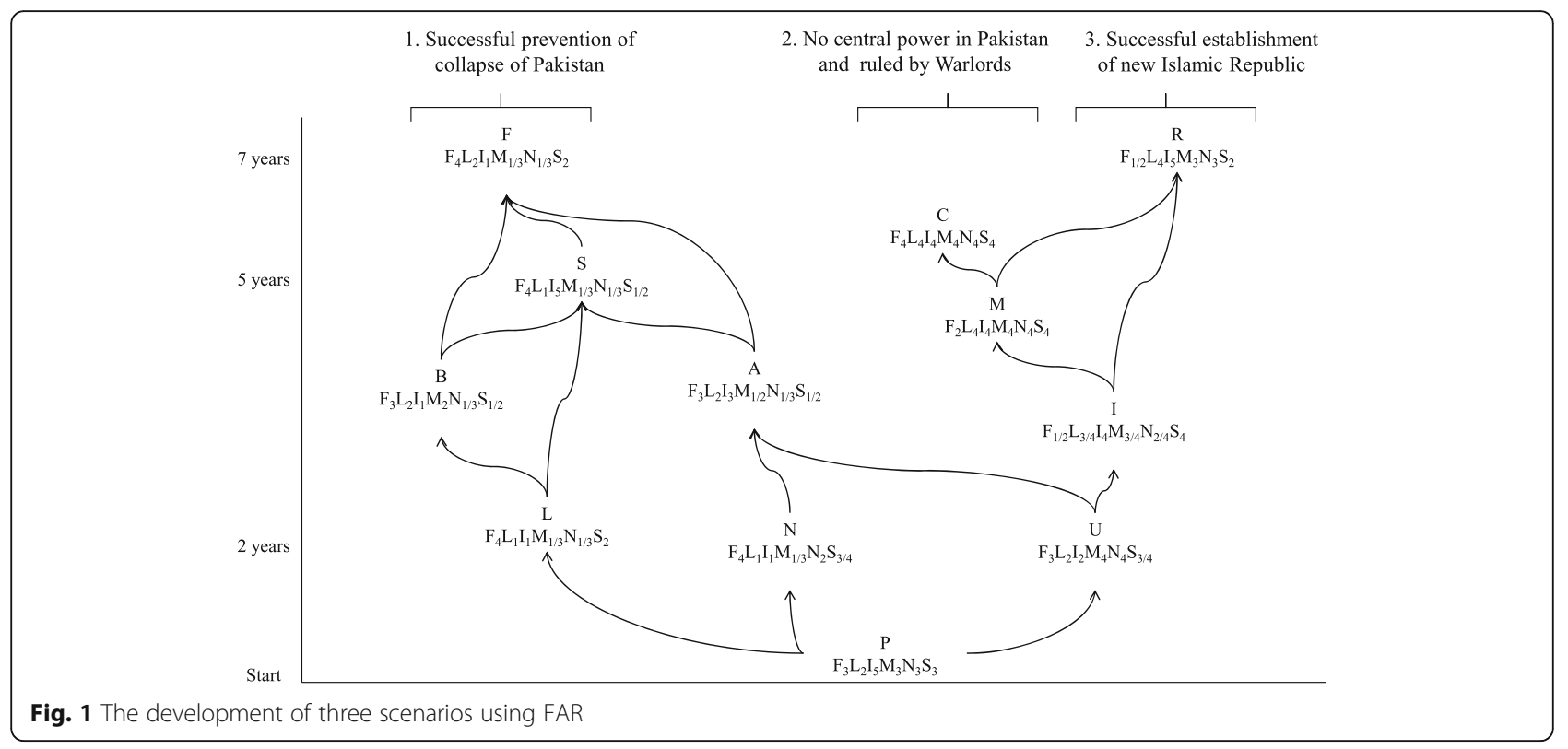

this allows decision makers to quickly identify 'decisive' points and also establish concrete goals. For instance, if the preferred future is scenario $\mathrm{F}$, then a loyalist-supported stability is required (World $\mathrm{S}-\mathrm{F}_{4} \mathrm{~L}_{1} \mathrm{I}_{5} \mathrm{M}_{1 / 3} \mathrm{~N}_{1 / 3} \mathrm{~S}_{1 / 2}$ ). Unfortunately, this is the point where most foresight practitioners stop. While these scenarios are a useful starting point, they still do not tell the decision maker (the NSC in this case) what their feasible action set is. FAR (along with most scenario development methods) does not provide probability.

\section{Step 2: What is probable?}

Understanding the probable requires a good sense of the system you are dealing with. Not just the components and connections in the system but also "understanding the properties, forces, patterns and interrelationships that shape the behaviours of the systems which provides options for actions" ([15], p. 48). Systems are generally understood in terms of three inters: interaction of components; inter-relationships of the processes within the system and interconnections between systems across time [16]. Mind maps and impact wheels were used to develop an understanding of the components and their relationships. These relationships were drawn on an influence diagram and the impact of time (indicated by $D_{1-3}$ where 3 takes longer than 1) was overlayed. This final product is illustrated in Fig. 2.

The influence diagram clearly displays a military loop and a civil-disruption loop. We can see that an increase in the level of economic growth contributes to the reduction in the influence of Muslim militant groups through the increase in the power of civilian government, an increase in trust of the traditional political system and a decrease in the number of available recruits. Conversely, we see that an increase in the level of foreign intervention will actually directly increase the influence of the Muslim militant groups. The influence diagram is an excellent way to see the macro connections and understand second and third order effects of an action. Unfortunately, it is difficult to visualise the sensitivity of the system to change.

A common practice in systems thinking and system dynamics is the use of models and simulation to understand the behaviour of a system. In this case, the influence diagram was translated into a stock and flow model in Powersim Studio [17]. The model (Fig. 3) allowed the system to be simulated using various values for each component in the system. The advantage of this method is that you can quickly understand where the system is sensitive to change. The disadvantage is that it requires an understanding of modelling and the appropriate simulation software. Regardless, the analysis of the simulations highlighted the importance of several 'levers' and the timings associated with the system changes. These levers are:

1. Importance of International Intervention-The effect of an international intervention is only felt if the strength of the militants is derived from the unsatisfied population. If the militants' sole source of strength is the Islamic Faction, it will ultimately wither and die. Unfortunately, conventional wisdom reveals that the Militants will draw strength from the large number of Madrassas and international terrorist organisations. 


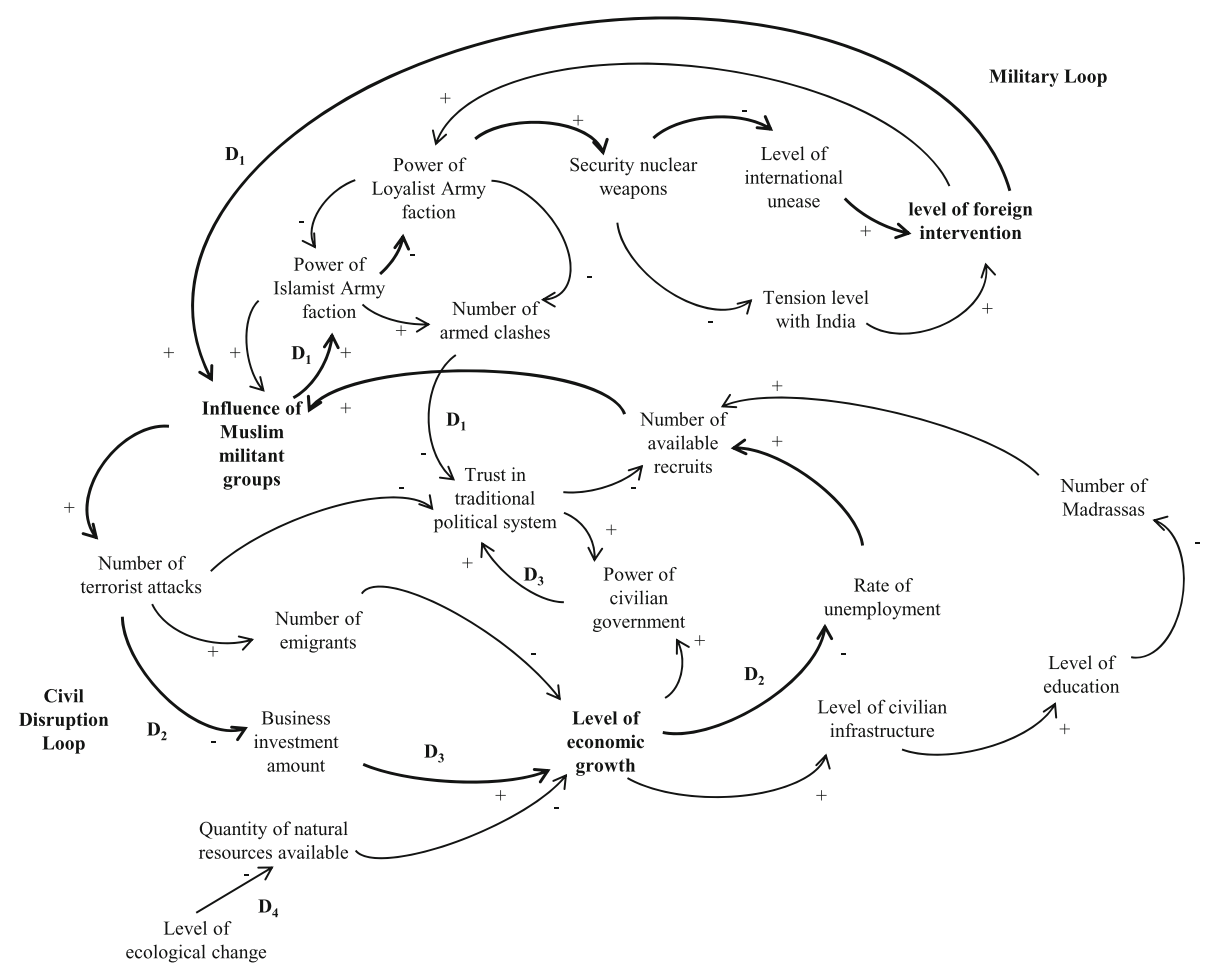

Fig. 2 Influence diagram showing significant loops and changes in the system over time

Summary of Factor strengths for scenario 1

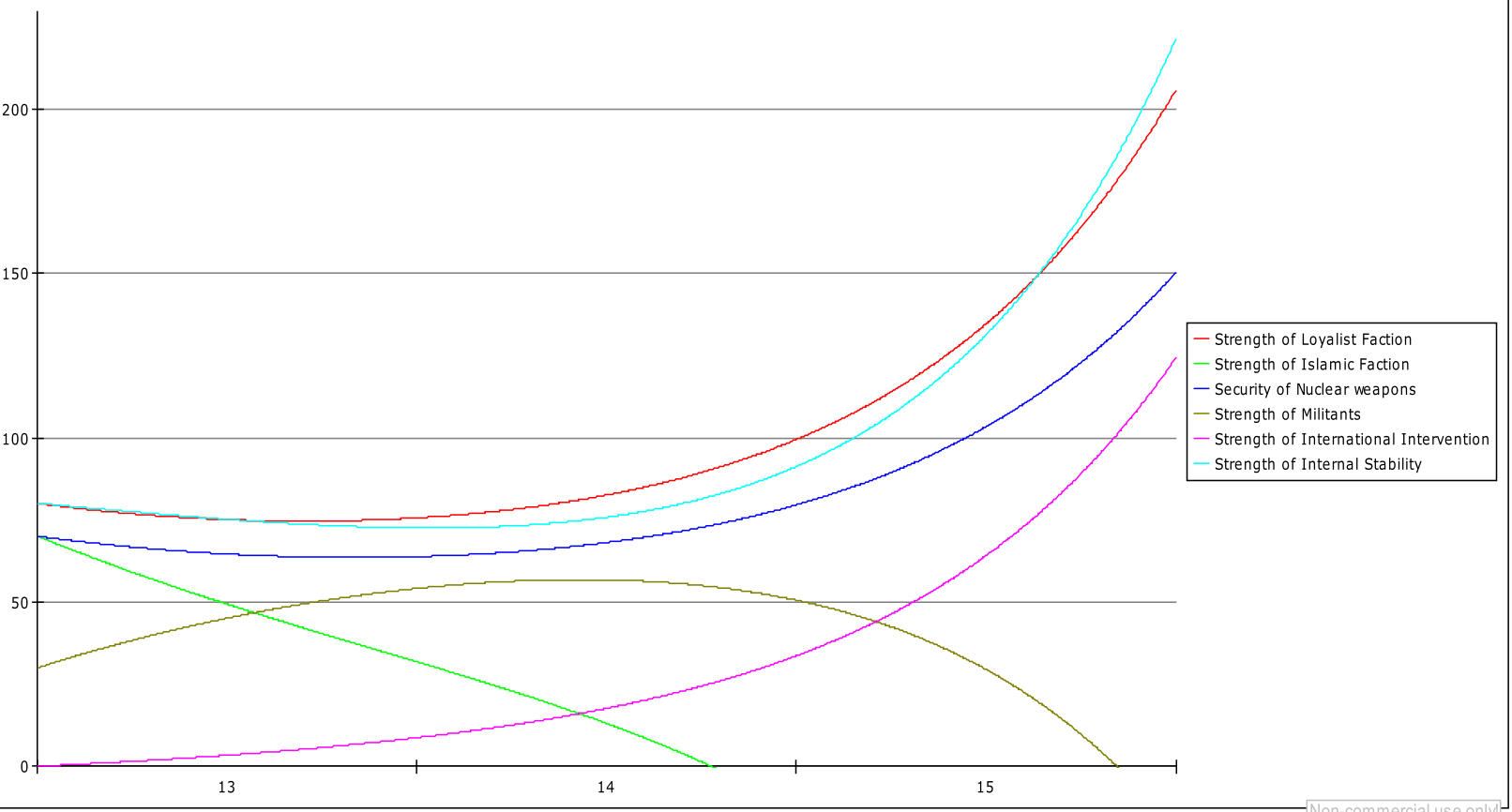

Fig. 3 Example output of a standard stock and flow simulation showing the sensitivity of an international intervention action 
2. Timing of International Intervention-If an intervention is left too late, such as when the Loyalists are ineffective, then the success of such an intervention is highly unlikely.

3. Importance of the security of nuclear weapons-The main incentive for the major powers to intercede in Pakistan is the security of the nuclear weapons. As soon as it is evident that the nuclear weapons are unsafe and not controlled, then a rapid response can be expected by the international community (particularly India and US).

4. Flow on effects - It is important also to understand the order of the flow-on effects. In this situation, most of the problems stem from the strength of the Islamic faction. By immediately reducing this factor, most of the other factors start to normalise.

\section{Step 3: What is actionable?}

While a relatively simple step, the development of a set of feasible options is one of the most critical points in this process. Up to this point, we have been exploring the operating environment. The next step is to create a number of actions that can influence that environment. In order to create a limited number of strategic options for the NSC, the Threats-Opportunities-WeaknessesStrengths (TOWS) technique was used ([14], p. 92). The TOWS is a reverse of the more commonly used SWOT. While the SWOT is more recognisable, the use of TOWS is very deliberate. While using this methodology, we have found that people who use SWOT appear to be more internally focused. Conversely, the key advantage of TOWS is that it examines the external environment (threats and opportunities) first. This ensures that the final options are responsive to the environment. Hence, TOWS is recommended over SWOT.

Table 3 identifies the external threats and opportunities (derived from steps 1 and 2) and internal strengths and weaknesses (derived from an understanding of the assets available to the NSC). Table 4 illustrates how the feasible actions are derived through a pairwise analysis (combining an external and internal factor to produce an action).

By examining the actions produced in TOWS Part 2 (Table 4), we can start to create a set of feasible options. As some of the actions are similar, we can derive three distinct options by creating sets of actions:

1. Option A (Actions 1, 5, 6, 9, 10): Develop a willing coalition of nations intent on securing the nuclear weapons

2. Option B (Actions 2, 4, 11): Provide humanitarian aid and limited training to stabilise Pakistan.

3. Option $C$ (Actions 3, 5, 7, 8): Conduct limited military strikes aimed at destabilising the Islamic faction and Militants and removing their centre of gravities
Table 3 TOWS part 1-understanding the external threats and opportunities and the internal weakness and strengths on the Pakistan nuclear problem

\begin{tabular}{cc}
\hline External threats & External opportunities \\
$T_{1}$ Islamic Faction controls some & $\mathrm{O}_{1}$ International fear of insecure \\
nuclear weapons & nuclear weapons \\
$\mathrm{T}_{2}$ Militants gain strength from & $\mathrm{O}_{2}$ Pakistan used to military rule \\
unstable nation & $\mathrm{O}_{3}$ US military and resources \\
$\mathrm{T}_{3}$ Militants are supported & $\mathrm{O}_{4}$ India Military and bases \\
by Islamic Faction & $\mathrm{O}_{5}$ Islamic and Militant forces \\
$\mathrm{T}_{4}$ Nation is becoming unstable & vulnerable to attack \\
$\mathrm{T}_{5}$ Pakistan unlikely to welcome & $\mathrm{O}_{6}$ Loyalists are well organised \\
external military forces & and ingrained in environment \\
$\mathrm{T}_{6}$ International will is lacking & \\
Internal weaknesses & Internal strengths \\
$W_{1}$ Limited available military & $\mathrm{S}_{1}$ Highly specialised forces \\
forces & $\mathrm{S}_{2}$ Relatively well respected \\
$W_{2}$ Takes time to mobilise & internationally \\
military forces & $\mathrm{S}_{3}$ Well organised humanitarian \\
$W_{3}$ Low pool of resources & relief strategies \\
&
\end{tabular}

The greatest benefit of this process is that there exists a trail of logic. We can see that Option B is a combination of actions 2,4 and 11 . These actions leverage the national strengths $\left(S_{1}, S_{2}, S_{3}\right)$ while mitigating threats $\left(\mathrm{T}_{2}, \mathrm{~T}_{4}, \mathrm{~T}_{5}\right)$ and taking advantage of a specific opportunity $\left(\mathrm{O}_{6}\right)$. The threats and opportunities were previously identified in the first two steps. It is also important to note that these options are not exclusive and can be employed at the same time. Variations in strategies would then look at the timing of each action (i.e. should limited military strikes be before or after a coalition is formed?). However, conventional wisdom understands that business cases and options papers need to consider the decision maker if they are to succeed. Thus, which option is the best or the most desirable for the NSC?

\section{Step 4: Which options are desirable?}

Desirability of an option is generally linked to the cost-benefit ratio and the associated risk attached to each action. This final step looks to understand where the risk is and which option provides the greatest return. ISO 31000 Risk Management clearly states that risk is the "effect of uncertainty on objectives"; hence, it is important not only to clearly understand our objective but also to understand what assumptions have been made in the development of the strategies to achieve that objective [18]. The other salient point to understand is that risk is made up of three components- "the magnitude of loss, the chance of loss and lastly the exposure to loss" ([19], p.9). This can be redefined as [risk=impact $\times$ likelihood] where chance and exposure are combined. The situation described in this paper is obviously complex with a multitude of risks. These risks are drawn out in Table 5 .

This short exercise has revealed that the top six threats to achieving our mission of stabilising Pakistan 
Table 4 TOWS part 2-creating a number of feasible actions by combining external with internal factors. Actions also show the internal and external factors they are sourced from

\begin{tabular}{|c|c|c|}
\hline & $\begin{array}{l}\text { External Threats } \\
\mathrm{T}_{1} \text { Islamic Faction controls some nuclear weapons } \\
\mathrm{T}_{2} \text { Militants gain strength from unstable nation } \\
\mathrm{T}_{3} \text { Militants are supported by Islamic Faction } \\
\mathrm{T}_{4} \text { Nation is becoming unstable } \\
\mathrm{T}_{5} \text { Pakistan unlikely to welcome external military } \\
\text { forces } \\
\mathrm{T}_{6} \text { International will is lacking }\end{array}$ & $\begin{array}{l}\text { External Opportunities } \\
\mathrm{O}_{1} \text { International fear of insecure nuclear weapons } \\
\mathrm{O}_{2} \text { Pakistan used to military rule } \\
\mathrm{O}_{3} \text { US military and resources } \\
\mathrm{O}_{4} \text { India Military and bases } \\
\mathrm{O}_{5} \text { Islamic and Militant forces vulnerable to attack } \\
\mathrm{O}_{6} \text { Loyalists are well organised and ingrained in } \\
\text { environment }\end{array}$ \\
\hline $\begin{array}{l}\text { Internal Weaknesses } \\
W_{1} \text { Limited available military forces } \\
W_{2} \text { Takes time to mobilise military forces } \\
W_{3} \text { Low pool of resources }\end{array}$ & 1. Build a coalition for an intervention $\left(W_{1}, W_{3}, T_{6}\right)$ & $\begin{array}{l}\text { 7. Focused military strikes on enemy leadership }\left(W_{1}, O_{5}\right) \\
\text { 8. Increase readiness of military forces for deployment } \\
\left(W_{2}, O_{5}\right)\end{array}$ \\
\hline $\begin{array}{l}\text { Internal Strengths } \\
\mathrm{S}_{1} \text { Highly specialised forces } \\
\mathrm{S}_{2} \text { Relatively well respected internationally } \\
\mathrm{S}_{3} \text { Well organised humanitarian relief } \\
\text { strategies }\end{array}$ & $\begin{array}{l}\text { 2. Deploy humanitarian forces to stabilise Pakistan } \\
\left(S_{3}, T_{4}, T_{2}\right) \\
\text { 3. Eliminate support links between Islamic Faction } \\
\text { and Militants }\left(S_{1}, T_{3}\right) \\
\text { 4. PR campaign that supports an international } \\
\text { intervention }\left(S_{2}, T_{5}\right) \\
\text { 5. Use } S F \text { to locate nuclear weapons }\left(S_{1}, T_{1}\right) \\
\text { 6. Lobby UN in support of intervention }\left(S_{2}, T_{6}\right)\end{array}$ & $\begin{array}{l}\text { 9. Focus international community on risk of unsecured } \\
\text { nukes to garner support }\left(\mathrm{S}_{2}, \mathrm{O}_{1}\right) \\
\text { 10. Form coalition with } U \mathrm{~S} \text { and India so as to leverage } \\
\text { their military assets }\left(\mathrm{S}_{2}, \mathrm{O}_{3}, \mathrm{O}_{4}\right) \\
\text { 11. Provide military training to Loyalists }\left(\mathrm{S}_{1}, \mathrm{~S}_{2}, \mathrm{O}_{6}\right)\end{array}$ \\
\hline
\end{tabular}

Table 5 Evaluating the risk of system components on the achievement of the objective

\begin{tabular}{|c|c|c|c|c|c|}
\hline & Description & Impact $(0-100)$ & Likelihood (0-10) & Risk & Rank \\
\hline & Loyalist & & & & \\
\hline $\mathrm{R}_{1}$ & No social support & 70 & 2 & 140 & 11 \\
\hline $\mathrm{R}_{2}$ & Unable to maintain public law and order & 50 & 3 & 150 & 8 \\
\hline $\mathrm{R}_{3}$ & Unable to suppress Islamic Faction & 80 & 5 & 400 & 3 \\
\hline \multirow[t]{2}{*}{$\mathrm{R}_{4}$} & Infiltration by Islamists & 20 & 6 & 120 & 13 \\
\hline & Militants & & & & \\
\hline $\mathrm{R}_{5}$ & Have widespread social support & 50 & 3 & 150 & 8 \\
\hline $\mathrm{R}_{6}$ & Can effectively exploit media and information systems & 30 & 4 & 120 & 13 \\
\hline \multirow[t]{2}{*}{$\mathrm{R}_{7}$} & Have international assistance & 50 & 6 & 300 & 5 \\
\hline & Islamic Faction & & & & \\
\hline $\mathrm{R}_{8}$ & Are willing to employ nuclear weapons & 90 & 3 & 270 & 7 \\
\hline \multirow[t]{2}{*}{$\mathrm{R}_{9}$} & Are able to counter capability of Loyalists & 80 & 5 & 400 & 3 \\
\hline & International Intervention & & & & \\
\hline $\mathrm{R}_{10}$ & India conducts first strike & 20 & 5 & 100 & 15 \\
\hline $\mathrm{R}_{11}$ & India not supportive & 60 & 1 & 60 & 18 \\
\hline$R_{12}$ & US not supportive & 70 & 1 & 70 & 16 \\
\hline \multirow[t]{2}{*}{$\mathrm{R}_{13}$} & Internal resistance to intervention is high & 70 & 6 & 420 & 2 \\
\hline & Internal Stability & & & & \\
\hline $\mathrm{R}_{14}$ & Low level of support for democracy or Loyalists & 70 & 2 & 140 & 11 \\
\hline $\mathrm{R}_{15}$ & High negative impact of global warming & 10 & 7 & 70 & 16 \\
\hline \multirow[t]{2}{*}{$R_{16}$} & Loss of law and order functions & 50 & 3 & 150 & 8 \\
\hline & Nuclear Capability & & & & \\
\hline $\mathrm{R}_{17}$ & Unable to locate all nuclear threats & 90 & 8 & 720 & 1 \\
\hline $\mathrm{R}_{18}$ & Willingness to utilise for short term gains & 100 & 3 & 300 & 5 \\
\hline
\end{tabular}


Table 6 Using congruence analysis to understand party preference to change from current world to preferred world

\begin{tabular}{llll}
\hline From & To & Pakistan & Intervening Government \\
$\mathrm{F}_{3} \mathrm{~L}_{2} \mathrm{M}_{3} \mathrm{~N}_{3} \mathrm{~S}_{3}$ & $\mathrm{~F}_{4} \mathrm{~L}_{1} \mathrm{I}_{1} \mathrm{M}_{1 / 3} \mathrm{~N}_{1 / 3} \mathrm{~S}_{2}$ & ++ & ++ \\
\hline $\mathrm{F}_{3}$ Weak Islamic faction & $\mathrm{F}_{4}$ Ineffective Islamic faction & ++ & + \\
$\mathrm{L}_{2}$ Strong Loyalist & $\mathrm{L}_{1}$ Dominating Loyalists & + & ++ \\
$\mathrm{I}_{5}$ No intervention & $\mathrm{I}_{1}$ Welcomed and effective intervention & + \\
$\mathrm{M}_{3}$ Supported but weak militants & $\mathrm{M}_{1 / 3}$ Supported / not supported but weak militants & + & + \\
$\mathrm{N}_{2}$ Known and unsafe nuclear weapons & $\mathrm{N}_{1 / 3}$ Known or unknown and Safe nuclear weapons & + & ++ \\
$\mathrm{S}_{3}$ Shaky internal stability & $\mathrm{S}_{2}$ Stable internal stability & + & ++
\end{tabular}

and securing the nuclear weapons are (note that risk 3 is a combination of $R_{3}$ and $R_{9}$ ):

1. Unable to locate all nuclear threats

2. Internal resistance to intervention is high

3. Loyalists are unable to suppress Islamic Faction

4. [militants] Have international assistance

5. Willingness to utilise [nuclear weapons] for short-term gains

The impact of these risks on the presented options is that for any intervention to succeed it needs to locate all nuclear threats as a priority (thus negating the temptation by opposing parties to use these weapons), ensuring that the Pakistan population is supportive and finally that the Loyalist Faction are equipped to win.

While a feasible set of options have been developed that address these risks, that does not necessarily equate to an automatic decision on the behalf of our elected representatives. Because this scenario will involve a high cost one way or another, we must consider the attitudes or emotional preferences of the decision makers. Murray-Webster and Hillson state that the "perception of risk is not an absolute, either present or absent, but is situational and highly dependent on a number of contextual factors" ([20], p.3). Sanbonmatsu et al. suggest that "the overall attitude towards an alternative is based on considerations of probability or weight" ([21], p., 106). This

Table 7 Evaluating the resource gap for each option and their sub-ordinate tasks

\begin{tabular}{|c|c|c|c|}
\hline Factor Sub-category & From & To & Resource Gap \\
\hline & $\mathrm{F}_{3}$ Weak Islamic faction & $\mathrm{F}_{4}$ Ineffective Islamic faction & \\
\hline \multirow[t]{2}{*}{ Focused military strikes on enemy leadership } & 1 & 3 & 2 \\
\hline & $\mathrm{L}_{2}$ Strong Loyalist & $\mathrm{L}_{1}$ Dominating Loyalists & \\
\hline Provide military training to Loyalists & 1 & 2 & 1 \\
\hline \multirow{2}{*}{$\begin{array}{l}\text { Form coalition with US and India so as to leverage } \\
\text { their military assets }\end{array}$} & 2 & 3 & 1 \\
\hline & $I_{5}$ No intervention & $I_{1}$ Welcomed and effective intervention & \\
\hline $\begin{array}{l}\text { PR campaign that supports an international } \\
\text { intervention }\end{array}$ & 2 & 3 & 1 \\
\hline Build a coalition for an intervention & 2 & 4 & 2 \\
\hline $\begin{array}{l}\text { Focus international community on risk of unsecured } \\
\text { nukes to garner support }\end{array}$ & 2 & 2 & 0 \\
\hline \multirow[t]{2}{*}{ Lobby UN in support of intervention } & 2 & 2 & 0 \\
\hline & $M_{3}$ Supported but weak militants & $\begin{array}{l}M_{1 / 3} \text { Supported / not supported but weak } \\
\text { militants }\end{array}$ & \\
\hline \multirow{2}{*}{$\begin{array}{l}\text { Eliminate support links between Islamic Faction } \\
\text { and Militants }\end{array}$} & 1 & 2 & 1 \\
\hline & $\begin{array}{l}\mathrm{N}_{2} \text { Known and unsafe nuclear } \\
\text { weapons }\end{array}$ & $\begin{array}{l}\mathrm{N}_{1 / 3} \text { Known or unknown and Safe nuclear } \\
\text { weapons }\end{array}$ & \\
\hline \multirow[t]{2}{*}{ Use SF to locate nuclear weapons } & 1 & 4 & 3 \\
\hline & $\mathrm{S}_{3}$ Shaky internal stability & $\mathrm{S}_{2}$ Stable internal stability & \\
\hline Deploy humanitarian forces to stabilise Pakistan & 2 & 2 & 0 \\
\hline
\end{tabular}


reasoning leads us to a point of view that decision making is highly individualised and often emotionally based-which is true. Fortunately, individuals within a group will often diffuse the responsibility and are more likely to take risks-thus, it would be fair to conclude that NSC is more likely to take a risk than not [22].

Before the decision is placed before the government, there is still a requirement to ensure that the presented options would rate well against the preferences of the interested parties. This is a process called congruence analysis. In our case, we are looking at proposing a limited intervention to support the Loyalists (or future $\mathrm{F}_{4} \mathrm{~L}_{1} \mathrm{I}_{1} \mathrm{M}_{1 / 3} \mathrm{~N}_{1 / 3} \mathrm{~S}_{2}$ ). Table 6 illustrates this technique.

This quick test demonstrates that a limited intervention that moves Pakistan from $\mathrm{F}_{3} \mathrm{~L}_{2} \mathrm{I}_{5} \mathrm{M}_{3} \mathrm{~N}_{3} \mathrm{~S}_{3}$ to $\mathrm{F}_{4} \mathrm{~L}_{1} \mathrm{I}_{1} \mathrm{M}_{1 / 3} \mathrm{~N}_{1 /}$ ${ }_{3} \mathrm{~S}_{2}$ is well in line with the preferences of both interested parties. The second test is to ensure that Intervening Government has the resources to undertake the chosen strategy. This combines the actions developed earlier with the change from current to preferred world as illustrated above. Table 7 demonstrates a resultant 'gap' indicates the ease of transition for Intervening Government.

It can now be seen that there will need to be a number of investments to ensure a successful strategy. For instance, a major investment into the use of Special Forces (SF) to locate nuclear weapons is needed as it is critical to success. Fortunately, some of the actions, such as "Lobby UN in support of intervention", already have sufficient resources to complete the action. Finally, we can recommend to the NSC that option B is immediately recommended due to low risk, low cost and high benefit; however, option A should be supported and pursued in the longer term.

\section{Conclusions}

Being able to generate future scenarios has always been a useful exercise; however, it appeared to lack a clear link with action. This demonstrated method allows for plausible future scenarios to be generated, analysed and used as a strong foundation to generate feasible strategic options. Where this method differs is the strong emphasis on developing a logical evidence chain that clearly links environment with option and preference. This then enables the analyst to confidently present their recommendation or amend the work should circumstances in the environment change dramatically.

The key advantage to this four-step process is the logical development of a chain of evidence. The key disadvantage is that this process requires more tools or methods, then would normally be expected from a foresight practitioner. That said, these methods are relatively well known and it is strongly recommended that foresight practitioners develop their systems thinking and understanding of systems dynamics.

Author's contribution

The author read and approved the final manuscript.

\section{Competing interests}

The author declares that they have no competing interests.

\section{Publisher's Note}

Springer Nature remains neutral with regard to jurisdictional claims in published maps and institutional affiliations.

Received: 31 July 2017 Accepted: 28 May 2018

Published online: 27 June 2018

References

1. Ritchey T (2011) General Morphological Analysis (GMA). In: Wicked problems-social messes. Springer, Berlin, pp 7-18

2. Sautter B (2016) Futuring European industry: assessing the ManuFuture road towards EU re-industrialization. European Journal of Futures Research 4(25) pp1-12

3. Bock K (2015) The changing nature of city tourism and its possible implications for the future of cities. European Journal of Futures Research 3(20) pp1-8

4. San-Jose L, Retolaza JL (2016) Is the Delphi method valid for business ethics? A survey analysis. European Journal of Futures Research 4(19) pp1-15

5. Cederquist A, Goluke U (2016) Teaching with scenarios: a social innovation to foster learning and social change in times of uncertainty. European Journal of Futures Research 4(17) pp1-8

6. Kononiuk A, Sacio-Szymanska A (2015) Assessing the maturity level of foresight in Polish companies - a regional perspective. European Journal of Futures Research 3(23) pp1-13

7. Sonk M (2015) How to justify beliefs about the future - some epistemological remarks. European Journal of Futures Research 3(17) pp1-6

8. Thomopoulos N, Givoni M (2015) The autonomous car-a blessing ot a curse for the future of low carbon mobility? An exploration of likely vs. desirable outcomes. European Journal of Futures Research 3(14) pp1-14

9. Krepinevich AF (2009) 7 deadly scenarios: a military futurist explores war in the 21st century. Bantam Books, New York

10. Inayatullah S (1998) Causal layered analysis: postructuralism as method. Futures 30(8):815-829

11. Inayatullah S (2014) Causal layered analysis defined. The Futurist 48(1):26

12. Reidy C (2008) An integral extension of causal layered analysis. Futures 40(2):150-159

13. Rhyne R (1995) Field anomaly relaxation: the arts of usage. Futures 37(6): 657-674

14. Coyle G (2004) Practical strategy: structured tools and techniques. Pearson Education Limited, Essex

15. Pisapia J, Reyes-Guerra D, Coukos-Semmel E (2005) Developing the leaders strategic mindset: establishing the measure. Leadership Review 5:41-68

16. Waldman JM (2007) Thinking systems need systems thinking. Systems Research and Behavioural Science 24(3):271-284

17. P. S. AS, "Home," 2017. [Online].Available: http://www.powersim.com/. [Accessed 31 July 2017]

18. Lark J, Nikonov V (2015) ISO 31000 Risk Management: a practical guide for SMEs. International Organization for Standardization, Geneva

19. MacCrimmon KR, Wehrung DA (1986) Assessing risk propensity. Recent developments in the foundations of utility and risk theory 47:291-309

20. Murray-Webster R, Hillson D (2008) Managing group risk attitude. Gower Publishing Ltd, Aldershot, pp1-190

21. Sanbonmatsu DM, Prince KC, Vanous S, Posavac SS (2014) The multiple roles of attitudes in decision making. In: The Routines of Decision Making. Tilmann B, Haberstroh S (eds). Psychology Press, pp101-116

22. Wallach M, Kogan N, Bem D (1964) Diffusion of responsibility and level of risk taking in groups. J Abnorm Soc Psychol 64(3):263-274 